\title{
Persepsi Siswa MIPA Kelas X Terhadap Pelaksanaan Proses Pembelajaran Biologi Berdasarkan Kurikulum 2013 SMAN 2 Bukittinggi
}

\section{Perceptions of MIPA Class X Students on the Implementation of Biology Learning Process Based on Curriculum 2013 SMAN 2 Bukittinggi}

\author{
Maria Fitri Andayani ${ }^{1}$, Destaria Sudirman ${ }^{2 *}$, Siska Arimadona $^{3}$ \\ ${ }^{123}$ Program Studi Pendidikan Biologi, STKIP Ahlussunnah, Bukittinggi \\ *Korespondensi : rhiasudirman@gmail.com
}

\begin{abstract}
Abstrak
Kurikulum 2013 bertujuan untuk menyeimbangkan antara pengetahuan, sikap, dan keterampilan bagi peserta didik. Tujuan dari penelitian ini yaitu untuk mengetahui bagaimana persepsi siswa MIPA Kelas X terhadap pelaksanaan proses pembelajaran Biologi berdasarkan kurikulum 2013 SMAN 2 Bukittinggi. Penelitian ini merupakan penelitian deskriptif yang datanya diperoleh melalui angket (kuesioner) yang diberikan kepada siswa. Teknik pengambilan sampel yang digunakan adalah Teknik Cluster Random Sampling. Data yang didapat diolah dengan menggunakan teknik persentase (\%). Berdasarkan analisa data yang diperoleh dari hasil penelitian dapat diketahui bahwa persepsi siswa MIPA kelas $\mathrm{X}$ terhadap pelaksanaan proses pembelajaran biologi berdasarkan kurikulum 2013 SMAN 2 Bukittinggi secara keseluruhan adalah cukup dengan persentase yaitu sebesar 79\%. Dari lima kegiatan dalam proses pembelajaran berdasarkan kurikulum 2013, terdapat dua kategori yaitu baik dan cukup. Dimana yang memiliki kategori baik yaitu pada kegiatan mengumpulkan informasi dan mengkomunikasikan, serta yang memiliki kategori cukup yaitu pada kegiatan mengamati, menanya, dan mengasosiasi.
\end{abstract}

Kata Kunci : Persepsi, Kurikulum 2013

\begin{abstract}
Curriculum 2013 aims to strike a balance between knowledge, attitudes, and skills for learners. The aims of this study are to determine how students' perceptions of Mathematics Class $X$ of the implementation of the learning process based on the biology curriculum in 2013 SMAN 2 Bukittinggi. This research is descriptive data obtained through questionnaires (questionnaires) were given to students of Mathematics. The data obtained were processed using techniques percentage (\%). Based on the analysis of data obtained from the research is that students' perceptions of Mathematics of class $X$ on the implementation of the learning process based on the biology curriculum in 2013 SMAN 2 Bukittinggi as a whole is simply the percentage that is equal to $79 \%$. Of the five activities in the learning process based on the curriculum of 2013, there are two categories: good and sufficient. Where that has both categories, namely the activities of collecting and communicating information, and which have enough category of the activity observed, ask, and associate.
\end{abstract}

Keyword : Perception, curriculum in 2013

\section{PENDAHULUAN}

Kurikulum yang sesuai dengan perkembangan dan tantangan zaman oleh generasi muda dalam proses pembelajaran pada saat sekarang ini yaitu kurikulum 2013 (Sunarti dan Selly, 2014). Kurikulum 2013 ini merupakan bentuk penyempurnaan atau pengembangan dari 
Maria Fitri Andayani, Destaria Sudirman, Siska Arimadona : Persepsi Siswa MIPA Kelas X....

kurikulum KTSP. Dalam proses pembelajaran kurikulum KTSP, tahapan kegiatan inti hanya terdiri atas 3 yaitu eksplorasi, elaborasi, dan konfirmasi. Dalam proses pembelajaran pada kurikulum KTSP siswa sudah dituntut untuk aktif. Sedangkan pada kurikulum 2013 siswa sudah dapat menemukan dan memecahkan sendiri masalah yang ditemukan dalam pembelajaran. Berubahnya kurikulum KTSP ke kurikulum 2013 ini merupakan salah satu upaya memperbaharui setelah dilakukannya penelitian untuk pengembangan kurikulum yang sesuai dengan kebutuhan generasi muda.

Kurikulum 2013 memadukan tiga konsep yang menyeimbangkan sikap, keterampilan, dan pengetahuan. Melalui konsep itu, keseimbangan antara hardskill dan softkill dimulai dari Standar Kompetesi Lulusan, Standar Isi, Stadar Proses, dan Standar Penilaian dapat diwujudkan. Kemudian kurikulum 2013 menggunakan pendekatan ilmiah dalam proses pembelajaran. Pendekatan ilmiah tersebut meliputi kegiatan mengamati, menanya, mengumpulkan informasi, mengasosiasikan, serta mengkomunikasikan, atau disebut juga dengan $5 \mathrm{M}$. Melalui pendekatan itu diharapkan nantinya siswa memiliki kompetensi sikap, keterampilan, dan pengetahuan yang lebih baik. Siswa juga akan lebih kreatif, inovatif, dan lebih produktif (Sunarti dan Selly, 2014). Selain itu, pola pembelajaran pada kurikulum 2013 menekankan kepada pembelajaran siswa aktif. Siswa dapat mencari dan menemukan sendiri melalui pendekatan saintifik, baik secara individu maupun kelompok. Dengan demikian siswa dapat memperoleh ilmu dari siapa saja dan darimana saja yang dapat dihubungi termasuk diperoleh melalui internet (Yusa dan Maniam, 2013).

Berdasarkan hasil wawancara penulis dengan Wakil Kurikulum SMAN 2 Bukittinggi, didapat informasi bahwa SMAN 2 Bukittinggi telah melaksanakan proses pembelajaran menggunakan kurikulum 2013 sejak tahun 2013. Guru dan Siswa juga telah diberi pemahaman mengenai bagaimana proses pembelajaran yang dilakukan berdasarkan kurikulum 2013. Walaupun demikian dalam memiplementasikan kurikulum 2013 ada beberapa faktor pendukung dan penghambat. Faktor pendukung dalam pelaksanaan implementasi kurikulum 2013 ini semangat para guru yang tinggi dalam usahanya mencari informasi tentang kurikulum 2013. Sedangkan factor penghambat dalam implementasi kurikulum 2013 para guru masih belum mampu menerapkan sepenuhnya pendekatan saintifik dalam proses pembelajaran dan masih cenderung mengunakan metode pembelajaran yang lama. Qomariyah (2014), melaporkan bahwa faktor penghambat dalam implementasi kurikulum 2013 adalah kebiasaan para guru masih menggunakan metode pembelajaran lama, 
kemampuan para siswa yang berbeda-beda, dan sarana prasana yang masih kurang. Berdasarkan paparan di atas, maka penulis tertarik melakukan penelitian tentang "Persepsi Siswa MIPA Kelas X Terhadap Pelaksanaan Proses Pembelajaran Biologi Berdasarkan Kurikulum 2013. Penelitian ini bertujuan Untuk mengetahui bagaimana persepsi siswa MIPA Kelas X terhadap pelaksanaan proses pembelajaran Biologi berdasarkan kurikulum 2013 SMAN 2 Bukittinggi.

\section{METODE PENELITIAN}

Penelitian ini merupakan penelitian deskriptif dengan populasi siswa MIPA Kelas X SMAN 2 Bukittinggi tahun pelajaran 2016/2017 yang berjumlah 220 orang siswa tersebar dalam 6 lokal. Teknik pengambilan sampel yang digunakan adalah Teknik Cluster Random Sampling. dimana setiap kelas diambil 25\% dari total jumlah siswanya. Teknik pengumpulan data yang digunakan berupa angket dengan menggunakan Skala Likert yang terdiri dari 5 alternatif jawaban. Kisi-kisi angket sebagai berikut;

Tabel 1. Kisi-kisi Angket

\begin{tabular}{llcc}
\hline \multicolumn{1}{c}{ Variabel } & \multicolumn{1}{c}{ Indikator } & No. item & Jumlah \\
\hline Persepsi Siswa MIPA & 1. Mengamati & $1-8$ & 8 \\
Kelas X Terhadap Proses & 2. Menanya & $9-16$ & 8 \\
Pembelajaran Biologi & 3. Mengumpulkan informasi & $17-24$ & 8 \\
Berdasarkan Kurikulum 2013 & 4. Mengasosiasikan & $25-32$ & 8 \\
& 5. Mengkomunikasikan & $33-40$ & 8 \\
\hline & \multicolumn{1}{c}{ Jumlah } & 40 \\
\hline
\end{tabular}

Sebelum angket ini digunakan, maka terlebih dahulu divalidasi oleh 3 orang dosen dan 1 orang guru. Selanjutnya data yang diperoleh dari instrument penelitian diolah dengan menggunakan teknik persentase (\%) (Purwanto, 2004).

\section{HASIL DAN PEMBAHASAN}

Tantangan dalam memecahkan masalah pembelajaran melalui kasus tergantung pada kemampuan guru untuk memilih dan mengekspos kasus berbasis biologis atau masalah di masyarakat (Suwono, et al., 2017). Berdasarkan hasil penelitian yang didapat setelah dilakukan pengolahan data dengan menggunakan teknik persentase (\%) dilihat dari jawaban angket responden yaitu siswa MIPA Kelas X SMA Negeri 2 Bukittinggi mengenai "Persepsi Siswa MIPA Kelas X Terhadap Pelaksanaan Proses Pembelajaran Biologi Berdasarkan Kurikulum 2013" dapat dilihat pada Tabel 2. 
Berdasarkan data hasil penelitian dari 5 kegiatan pada tahapan kegiatan inti dalam proses pembelajaran berdasarkan kurikulum 2013, terdapat 2 kategori persepsi siswa yaitu kategori cukup dan baik. Untuk kategori baik berada dalam rentang 80-89\%, dimana untuk kategori baik ini terdapat pada dua kegiatan yaitu kegiatan mengumpulkan informasi 80,79\% dan mengkomunikasikan 80,70\%. Sedangkan untuk kategori cukup berada dalam rentang 6579\%, Dimana untuk kategori cukup ini terdapat tiga kegiatan yaitu mengamati 77,32\%, menanya $77,89 \%$, dan mengasosiasi $79,17 \%$.

Tabel 2. Pengelompokkan Data Hasil Penelitian Berdasarkan Indikator

\begin{tabular}{cclcccc}
\hline \multirow{2}{*}{ No } & $\begin{array}{c}\text { Item } \\
\text { Instrumen }\end{array}$ & \multicolumn{1}{c}{ Indikator } & $\begin{array}{c}\text { Jumlah Skor } \\
\text { Item }(\mathrm{R})\end{array}$ & $\begin{array}{c}\text { Jumlah Skor } \\
\text { Max (N) }\end{array}$ & Persentase & Kategori \\
\hline 1 & $1-8$ & Mengamati & 1670 & 2160 & $77,32 \%$ & Cukup \\
2 & $9-16$ & Menanya & 1682 & 2160 & $77,89 \%$ & Cukup \\
3 & $17-24$ & Mengumpulkan & 1745 & 2160 & $80,79 \%$ & Baik \\
& & Informasi & & & & \\
4 & $25-35$ & Mengasosiasikan & 1710 & 2160 & $79,17 \%$ & Cukup \\
5 & $33-40$ & Mengkomunikasikan & 1743 & 2160 & $80,70 \%$ & Baik \\
\hline $\begin{array}{l}\text { Persepsi Siswa MIPA Kelas X } \\
\text { Terhadap Pelaksanaan Proses }\end{array}$ & & & & \\
$\begin{array}{l}\text { Pembelajaran Biologi Berdasarkan } \\
\text { Kurikulum 2013 }\end{array}$ & & & & & \\
\hline
\end{tabular}

Berdasarkan dua kegiatan pada kategori baik yang memiliki persentase tertinggi adalah pada kegiatan mengumpulkan informasi dengan persentase 80,79\%. Hal ini disebabkan karena pada kegiatan ini siswa merasa puas karena bisa mengumpulkan informasi dari berbagai sumber, dan siswa dapat mengumpulkan informasi sendiri atau berkelompok bersama temannya, sehingga melalui mengumpulkan informasi siswa akan bisa melatih dirinya dalam mengembangkan sikap teliti, jujur, sopan, dan menghargai pendapat sesama teman. Pada kegiatan mengumpulkan informasi ini juga dapat mengasah siswa untuk dapat berfikir kritis dan membuat siswa menjadi lebih mandiri dalam belajar. Proses seperti ini mendukung pembelajaran kooperatif. Pembelajaran kooperatif tipe Think Pair Square bisa mengatasi sifat pasif siswa dalam belajar, karena siswa dituntut untuk berpikir secara mandiri, berbagi dengan pasangannya dan bekerja dalam kelompok. Model pembelajaran TPSq yang dikombinasikan dengan Problem Solving lebih tinggi dari pada dengan menggunakan metode ceramah, hal disebabkan karena model pembelajaran TPSq ini menjadikan siswa termotivasi untuk belajar biologi (Masrudi, Sudirman dan Ramses, 2016). Menutut Prayitno et al., (2017) pembelajaran kooperatif, baik individu maupun yang terintegrasi dengan model pembelajaran lainnya dianjurkan untuk diterapkan di kelas sains untuk meningkatkan prestasi akademik 
atau kemampuan proses sains agar siswa lebih rendah, daripada menerapkan pembelajaran berbasis persaingan yang dapat menciptakan kesenjangan antara tinggi dan rendah.

Hal ini sesuai dengan apa yang dinyatakan dalam Permendikbud No. 81A Th. 2013 bahwa mengumpulkan informasi akan melatih siswa mengembangkan sikap teliti, jujur, sopan, menghargai pendapat orang lain, kemampuan berkomunikasi, menerapkan kemampuan mengumpulkan informasi melalui berbagai cara yang dipelajari, mengembangkan kebiasaan belajar dan belajar sepanjang hayat. Contoh mengumpulkan informasi diantaranya siswa melakukan eksperimen, siswa membaca sumber lain selain buku teks, siswa mengamati objek/kejadian/ aktivitas, siswa mewawancarai nara sumber, dan siswa berdiskusi (Yusa dan Maniam, 2013).

Kemudian dari tiga kegiatan yang tergolong pada kategori cukup, yang memiliki persentase terendah yaitu terdapat pada kegiatan mengamati, dengan persentase $77,32 \%$. Hal ini disebabkan karena kurangnya kesungguhan siswa dalam melihat dan memperhatikan materi yang diberikan oleh guru dalam proses pembelajaran. Yusa dan Maniam (2013) mengatakan berdasarkan Permendikbud No. 81A Th. 2013, bahwa mengamati melatih siswa dalam hal kesungguhan, ketelitian, dan mencari informasi. Dalam kegiatan mengamati, guru membuka secara luas dan bervariasi kesempatan peserta didik untuk melakukan pengamatan melalui kegiatan melihat, menyimak, mendengar, dan membaca yang diformulasikan pada skenario proses pembelajaran.

Berdasarkan analisis data yang telah dilakukan, maka dalam penelitian ini dapat digambarkan secara umum mengenai persepsi siswa MIPA Kelas X terhadap pelaksanaan proses pembelajaran biologi berdasarkan kurikulum 2013 SMAN 2 Bukittinggi termasuk kategori cukup dengan persentase 79,17\%. Hal ini dikarenakan proses pembelajaran biologi di kelas X MIPA SMAN 2 Bukittinggi telah terlaksana berdasarkan kurikulum 2013 yang terdiri dari kegiatan mengamati, menanya, mengumpulkan informasi, mengasosiasi, dan mengkomunikasikan. Yusa dan Maniam (2013) bahwa proses pembelajaran berdasarkan kurikulum 2013 terdiri atas 5 pengalaman belajar pokok yaitu mengamati, menanya, mengumpulkan informasi, mengasosiasi, dan mengkomunikasikan yang dikenal dengan $5 \mathrm{M}$ pada pendekatan saintifik. 


\section{KESIMPULAN}

Berdasarkan hasil penelitian, dapat disimpulkan bahwa persepsi siswa MIPA kelas X terhadap pelaksanaan proses pembelajaran biologi berdasarkan kurikulum 2013 SMAN 2 Bukittinggi secara keseluruhan adalah cukup dengan persentase 79,17\%. Dari lima kegiatan dalam proses pembelajaran berdasarkan kurikulum 2013, terdapat dua kategori yaitu baik dan cukup. Dimana yang memiliki kategori baik yaitu pada kegiatan mengumpulkan informasi dan mengkomunikasikan, serta yang memiliki kategori cukup yaitu pada kegiatan mengamati, menanya, dan mengasosiasi atau mengolah informasi.

\section{REFERENSI}

Arikunto. S., 2006. Prosedur penelitian. Rineka Cipta. Jakarta.

Sofian, E. dan Tukiran. 2012. Metode Penelitian Survei. LP3ES. Jakarta.

Nurhamidah, S., Dantes, N., Lasmawan, W., 2014. Upaya Peningkatan Pengelolaan Proses Pembelajaran Melalui Pendampingan Pada Implementasi Kurikulum 2013 Terhadap Guru-Guru Kelas I Dan Kelas IV. Jurnal Penelitian Pascasarjana Undiksha. 4(1):111.

Masrudi, Sudirman, D., Ramses 2016. The Effect Of The Cooperative Learning Model; Think pair square type (Tpsq) and Problem Solving Approach Combination Toward Students' Biology Learning Outcomes At class VIII SMPN 5 Batam. Simbiosa, 5 (1): 56-67. http://journal.unrika.ac.id/index.php/simbiosajournal/article/view/811

Prayitno, B. A., Corebima, D., Susilo, H., Zubaidah S. \& Ramli, M., 2017, Closing The Science Process Skills Gap Between Students With High And Low Level Academic Achievement. Journal of Baltic Science Education,. 16 (2): 266-277

Purwanto. 2004. Prinsip-prinsip dan Tekhnik Evaluasi. Remaja Karya. Bandung.

Qomariyah. 2014. Kesiapan Guru dalam Menghadapi Implementasi Kurikulum 2013. Jurnal Pendidikan Ekonomi IKIP Veteran Semarang. 2 (1): 21-35

Fitriany, R. A. M., dan Susilo, H., 2014. Analisis Hambatan Proses Pembelajaran Biologi Dan Cara Pemecahannya Dalam Pelaksanaan Kurikulum 2013 Bagi Guru Kelas X SMA Negeri Se-Kota Lamongan. 1-15. http://jurnal-online.um.ac.id/data/artikel/ artikelDBBF4022919DBFA26ECA90FFB CF253 E4.pdf

Rusman. 2009. Manajemen Kurikulum. PT Raja Grafindo Persada. Jakarta.

Sanjaya, W., 2008. Kurikulum dan Pembelajaran. Kencana. Jakarta. 
Suwono, H., Pratiwi, H. E., Susanto, Susilo, H. H., 2017. Enhancement of students' biological literacy and critical thinking of biology through socio-biological case-based learning. JPII, 6 (2): 213-220. http://journal.unnes.ac.id/index.php/jpii

Sunarti dan Selly, R., 2014. Penilaian Dalam Kurikulum 2013. ANDI. Yogyakarta.

Yusa dan Maniam, M. B. S., 2013. Buku Guru Aktif dan Kreatif Belajar Biologi Kurikulum 2013. Grafindo Media Pratama. Bandung. 